\title{
Smoking Behavior: How Close to the Tipping Do Consumers Actually Smoke?*
}

\author{
by \\ F.K. St.Charles ${ }^{1,2}$, A.A. Kabbani ${ }^{1,3}$, and M.W. Ogden ${ }^{4}$ \\ ${ }^{1}$ Formerly of Brown and Williamson Tobacco Company, Macon, GA, USA 31202 \\ ${ }^{2}$ Current address: 112 Raven Avenue, Perry 31069, GA, USA E-mail: saintc1@alltel.net \\ ${ }^{3}$ Current address: 245 College Street, Macon 31201, GA, USA \\ ${ }^{4}$ R.J. Reynolds Tobacco Company, Winston-Salem 27102, NC, USA
}

\section{SUMMARY}

When smoked by the Federal Trade Commission (FTC) method, the standard butt length for filtered cigarettes is specified as tipping plus $3 \mathrm{~mm}$. One of the criticisms of this standard is that the tipping overlap hides some of the tobacco column and that consumers actually smoke cigarettes past the tipping.

The objective of this study was to determine how consumers actually smoke their usual brand when smoking in their everyday environment. A portable device was designed to collect and preserve cigarettes from consumers after smoking. In use, the smoldering cigarette is dropped into the device and it is closed. Upon closing, the cigarette is extinguished, the mouth end of the filter is cut and separated for further analysis, and the date and time are recorded.

Fifty adult smokers per brand were recruited across 5 US cities (10 smokers/city). A wide range of brands was studied: menthol and non-menthol, $1 \mathrm{mg}$ to $18 \mathrm{mg}$ FTC 'tar' yield, 17 to $25 \mathrm{~mm}$ circumference, and both 85 and $100 \mathrm{~mm}$ lengths. A total of 10528 cigarettes from 803 subjects covering 17 brands was measured.

The subjects were provided with one pack of their usual brand, as well as a collection device, and were instructed on how to use the device. The devices were collected on subsequent days. The cigarettes were then removed and the distance from the tipping to the char line was measured. The overall median butt length was tipping plus $6.7 \mathrm{~mm}$ with an overall average of tipping plus $8.4 \mathrm{~mm}$. There was no significant effect of FTC 'tar' yield on either mean ( $p=$ $0.72)$ or median $(p=0.92)$ butt length. [Beitr. Tabakforsch. Int. 21 (2005) 435-440]

\section{ZUSAMMENFASSUNG}

Beim Abrauchen von Zigaretten nach Methode der Federal Trade Commission (FTC) ist die Stummellänge von Filterzigaretten standardmäßig auf $3 \mathrm{~mm}$ zuzüglich Belagpapier festgelegt. Einer der Kritikpunkte an diesem Standard besteht darin, dass der überstehende Teil des Belagpapiers einen Teil des Tabakstrangs verdeckt und Konsumenten Zigaretten über das Belagpapier hinaus rauchen.

Ziel dieser Untersuchung war es herauszufinden, wie Konsumenten in ihrem alltäglichen Umfeld ihre Zigarettenmarke gewöhnlich rauchen. Es wurde eine tragbare Vorrichtung entwickelt, in der die Zigaretten nach dem Rauchen gesammelt und aufbewahrt wurden. Hierbei wurde die glimmende Zigarette in dem Behältnis aufgefangen und dieses wurde dann verschlossen. Beim Verschließen des Behältnisses erlischt die Zigarette, das Mundstückende des Filters wird abgeschnitten und für weitere Analysen aufbewahrt, außerdem werden Datum und Uhrzeit vermerkt.

Pro Zigarettenmarke wurden 50 erwachsene Testpersonen in fünf US amerikanischen Städten rekrutiert (10 Raucher pro Stadt). Eine große Bandbreite von Zigarettenmarken wurde untersucht: Zigaretten mit und ohne Menthol, Zigaretten mit 1 bis $18 \mathrm{mg}$ FTC Kondensat, Zigaretten mit 17 bis $25 \mathrm{~mm}$ Umfang sowie 85 und $100 \mathrm{~mm}$ lange Zigaretten. Insgesamt wurden 10528 Zigaretten 17 verschiedener Marken, die von 803 Testpersonen geraucht worden waren, untersucht.

Die Testpersonen bekamen eine Packung ihrer gewohnten Sorte sowie ein Sammelbehältnis und wurden in dessen Benutzung unterwiesen. Die Behältnisse wurden an den darauf folgenden Tagen eingesammelt. Die Zigaretten wurden entfernt und der Abstand vom Belagpapier bis zur Brennlinie wurde gemessen. Die mediane Stummellänge

*Received: $19^{\text {th }}$ May 2005 - accepted: $13^{\text {th }}$ October 2005 
betrug 6,7 mm zuzüglich Belagpapier, die durchschnittliche Stummellänge lag bei $8,4 \mathrm{~mm}$ zuzüglich Belagpapier. Der FTC Kondensatwert hatte weder auf die mediane $(p=0,72)$ noch auf die mittlere Stummellänge $(p=0,92)$ einen statistisch signifikanten Einfluss. [Beitr. Tabakforsch. Int. 21 (2005) 435-440]

\section{RESUME}

En conditions normalisées FTC (Federal Trade Commission), la longueur standard des mégots des cigarettes filtres est spécifiée comme étant celle de la manchette plus $3 \mathrm{~mm}$. Une des critiques formulées à l'encontre de cette norme est que la manchette recouvre une partie de la colonne de tabac et que les fumeurs fument effectivement les cigarettes au delà de la manchette.

L'objectif de cette étude est de déterminer comment les fumeurs fument réellement leur marque habituelle dans leur environnement quotidien. Un appareil portable a été conçu pour échantillonner et conserver les cigarettes après fumage. En cours d'utilisation, la cigarette en combustion est introduite dans cet appareil d'échantillonnage qui est fermé ensuite. Après la fermeture, la cigarette est éteinte, l'extrémité buccale de la manchette est coupée et séparée pour des analyses supplémentaires. De plus, la date et l'heure sont consignées.

Cinquante fumeurs adultes ont été recrutés dans cinq villes des Etats-Unis. Une large gamme de marques a été examinée : des cigarettes avec ou sans menthol, de 1 à $18 \mathrm{mg}$ de goudron FTC, d'une circonférence de 17 à $25 \mathrm{~mm}$, et des cigarettes de 85 et $100 \mathrm{~mm}$ de longueur. Un total de 10.528 cigarettes, fumées par 803 sujets couvrant 17 marques a été analysé. Les sujets ont reçu un paquet de leur marque habituelle ainsi qu'un appareil d'échantillonnage et ils ont été instruits pour son utilisation. Les appareils ont été recueillis les jours suivants. Les cigarettes ont été retirées et la distance de la manchette jusqu'à la ligne de combustion a été mesurée. La longueur médiane du mégot est de $6,7 \mathrm{~mm}$ plus la manchette, la longueur moyenne est de $8,4 \mathrm{~mm}$ plus la manchette. Il n'y a pas d'effets significatifs du rendement en goudron FTC sur la longueur moyenne $(p=0,72)$ et sur la longueur médiane $(p=0,92)$ du mégot. [Beitr. Tabakforsch. Int. 21 (2005) 433-438]

\section{INTRODUCTION}

A concern has been expressed that wider tipping paper is used to increase the amount of nicotine a smoker can obtain from a cigarette over the advertised Federal Trade Commission (FTC) yield $(1,2)$ and that smoking down to the filter is a method of compensatory smoking (3). One of the proposed changes to the machine smoking method is to smoke down to the filter (4).Very little information was found in the literature which describes how close to the tipping consumers actually smoke their cigarettes, although there have been studies that reported the total butt length (including the filter) of consumer smoked cigarettes. Large scale studies were carried out in Germany covering the period from 1959 to 1982 which reported the overall butt lengths for filtered and unfiltered cigarettes (5-9). Typical sample sizes for these studies ranged from 20,000 to 40,000 cigarettes for each sampling period except for the 1959 study which measured about 2000 cigarettes. For these studies, the average butt lengths for filtered cigarettes (including the filter) increased from $22.1 \mathrm{~mm}$ in 1959 to $33.8 \mathrm{~mm}$ in August $1972(5,6,9)$. A slight decrease $(0.58 \mathrm{~mm})$ was noted in average butt length between August and October 1972 which was attributed to a tax increase in Germany $(6,9)$. A further decrease in the average butt length of filtered cigarettes to $32.78 \mathrm{~mm}$ was found in 1974 which was attributed to the economic influence of a recession $(7,9)$. Average butt lengths of filtered cigarettes then increased to $33.70 \mathrm{~mm}$ in 1978 and $33.55 \mathrm{~mm}$ in 1979 followed by a decrease to $33.24 \mathrm{~mm}$ in 1983 following another tax increase (8). Other values have been reported as part of small scale ( $N=4$ to 32 subjects) laboratory studies $(10,11,12)$. RAWBONE et al. (10) report mean "tobacco butt lengths" between 7.3 and $12.1 \mathrm{~mm}$ for groups of 4 to 7 smokers but it is unsure whether this value is relative to the filter or tipping. CREIGHTON and LEWIS (11) report total butt lengths for a switching study with 16 panelists smoking a total of 480 cigarettes. Tipping lengths for the cigarettes were reported which allowed the mean butt length relative to the tipping to be calculated as tipping plus 10.1 mm. ADAMS (12) reported mean butt lengths ranging from tipping plus $4.8 \mathrm{~mm}$ to tipping plus $9.2 \mathrm{~mm}$ for a 10 -week switching study with 32 subjects. A more recent study has reported the measurement of butt lengths as part of an overall smoking behavior study of 131 smokers. The average butt lengths (including the filter) were $37.6 \mathrm{~mm}$ for low nicotine yield brands and $34.2 \mathrm{~mm}$ for medium nicotine yield brands (13). Another more recent study reported a mean butt length of $33.2 \mathrm{~mm}$ for over 2000 cigarettes as part of a study on mouth insertion depth (14).

The objective of this study was to determine how close to the tipping adult US consumers smoke their own product in their everyday environment. A further objective was to determine if smoking into the tipping overlap is used as a method of compensatory smoking.

\section{EXPERIMENTAL}

\section{Sample collection}

A portable device (Greene Machine \& Mfg., Macon, GA) was used to collect and preserve cigarettes from consumers after smoking (Figure 1). Dimensions were $170 \mathrm{~mm} \times 110$ $\mathrm{mm} \times 28 \mathrm{~mm}$ and weight was approximately $370 \mathrm{~g}$. Figure $1 \mathrm{~A}$ shows an external view, $1 \mathrm{~B}$ shows a view with the cover removed, and $1 \mathrm{C}$ shows an internal view where the cigarettes were stored. When a subject was finished with their cigarette, they would pull the metal handle to the right and drop the smoldering cigarette into the hole shown next to the "Filter in First" label (Figure 1A). They were instructed to drop the cigarette in filter first and would usually, but not always, comply. Figure $1 \mathrm{C}$ shows one of the cigarettes dropped in coal first. In this case the length smoked could not be measured.

They would then close the device by moving the handle back to the left. Upon closing, a sliding plunger would push the cigarette past a micro switch and scalpel blade and into a storage compartment. The micro switch was connected to 


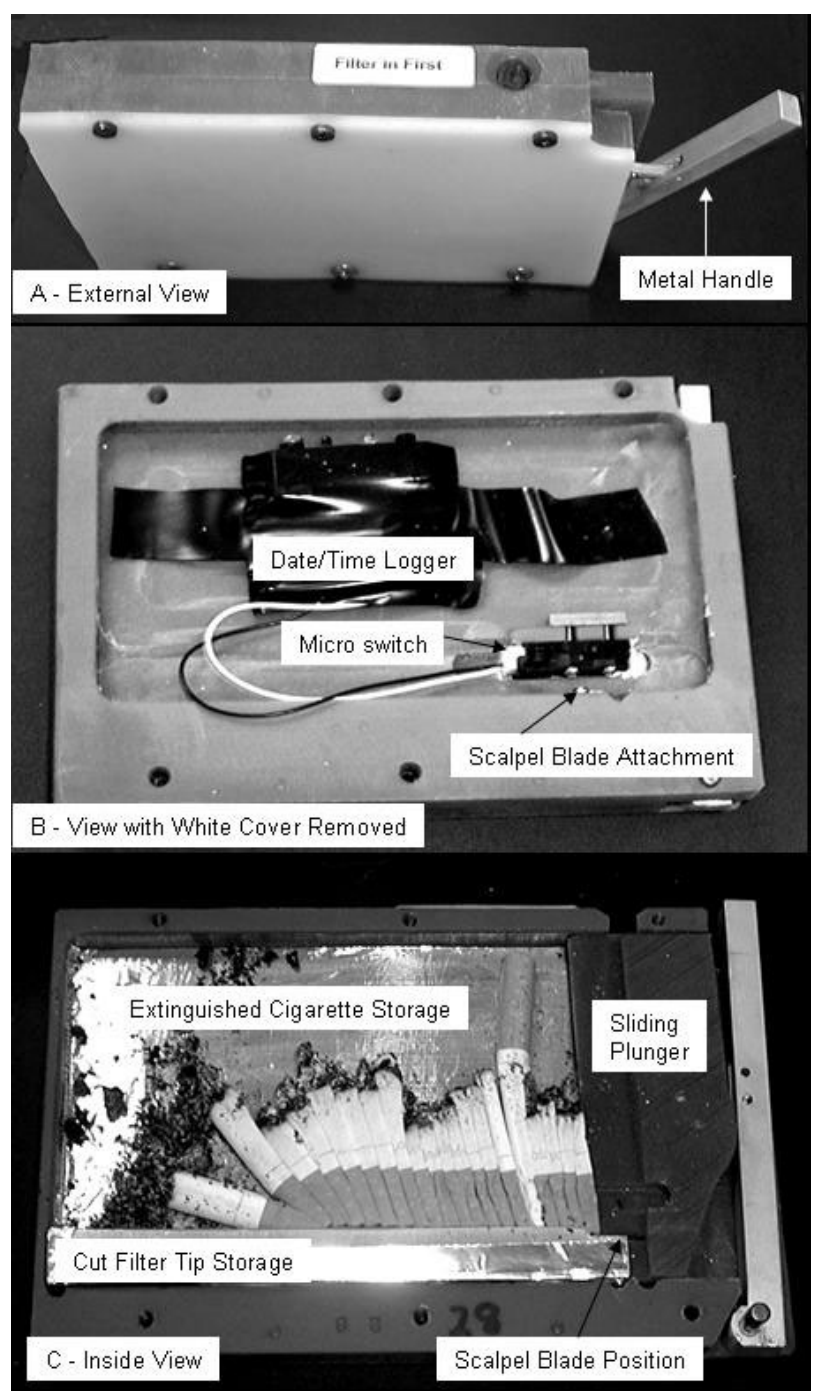

Figure 1. Device used to collect and store smoked cigarettes (A - external view, B - view with cover removed, C - internal view)

a $\mathrm{HOBO} ®$ State, and later a HOBO® Event, Date/Time logger (Onset Computer Corp., Pocasset, MA). The scalpel blade cut a $1 \mathrm{~cm}$ portion from the filter for later analysis. This was stored in an aluminum compartment separated from the remainder of the cigarette. The compartment used for extinguished cigarette storage was lined with aluminum and had a spacing of $6 \mathrm{~mm}$ between the two sides. This would compress and hold the cigarette and extinguish it within seconds.

\section{Subjects}

Fifty adult smokers for each of 17 cigarette brandstyles were recruited across 5 US cities: Portland, OR; San Diego, CA; Chicago, IL; New York, NY; and Atlanta, GA. Subject demographics (age, sex, and race) were chosen to approximate the national demographics for the particular brand being studied. All subjects were over the age of 21 and gave informed consent to participate in the study. Subjects were given a small compensation for participating in the study. A marketing research firm (Guideline Chicago, Lombard, IL) was used to recruit smokers, pass out one pack of their usual brand along with the collectors, instruct the subjects on use of the collector, retrieve the collectors by appointment, and then ship the collectors to the Brown \& Williamson laboratory.

\section{Measurement}

Upon receipt, the collectors were opened and the length from the tipping to the char line was measured. If the char line had not reached the tipping, the length was measured to the nearest millimeter with a ruler. For a slanted char line, the length was measured at the approximate mid point. If the char line had reached the tipping, the remaining tobacco was removed and the distance from the filter to the char line was measured with a vernier caliper. The tipping overlap was then subtracted from this measurement.

\section{Brand selection}

Seventeen US brands were chosen to represent a wide range of styles. A summary is shown in Table 1 . All brands but Brand I (due to circumference) were collected using the collection device. For this brand, subjects were asked to manually break the filter from the cigarette. Filters were stored in a metal tube and tobacco columns were stored in an empty package. Compliance for collecting tobacco columns using this method was not as good as using the collection device and gave a cigarette count less than half that of the other brands.

\section{RESULTS}

Throughout this discussion all lengths will be referenced to the edge of the tipping overlap. A positive value means that the char line had not reached the edge of the tipping. A value of zero means that the char line was at the edge of the tipping. A negative value means that the char line was between the edge of the tipping and the filter. The tipping overlap onto the tobacco column ranged from 4 to $6 \mathrm{~mm}$ for individual brands. For example, a butt length of $3 \mathrm{~mm}$ refers to tipping plus $3 \mathrm{~mm}$. Overall, a total of 10528 cigarettes from 803 subjects was measured. Table 2 contains the mean \pm standard deviation (SD) and median for each brand and all brands combined on both a cigarette and subject basis. A cigarette basis means that the lengths for all cigarettes of a given brand were combined. This tends to weight the data toward the subjects that returned more cigarettes but gives a better indication of the overall variability of the butt lengths measured. A subject basis uses the mean butt lengths for each subject. This eliminates the weighting toward subjects that returned more cigarettes and gives an indication of subject-to-subject variability. The median values are less than the mean values for all brands which indicates a non-normal distribution with a skew to the higher values.

Figure 2 is a histogram of the combined data for the individual cigarette measurements along with a cumulative per cent curve. The values on the horizontal axis are the distance from the edge of the tipping overlap. The values on the left vertical axis refer to the histogram. The height of each column represents the number of cigarettes with a given butt length. The values on the right vertical axis refer 
Table 1. Brands studied

\begin{tabular}{l|c|c|c|c|c|c|c|c}
\hline Code & $\begin{array}{c}\text { FTC 'tar' } \\
(\mathrm{mg})\end{array}$ & $\begin{array}{c}\text { Nominal length } \\
(\mathrm{mm})\end{array}$ & $\begin{array}{c}\text { Nom. circ. } \\
(\mathrm{mm})\end{array}$ & $\begin{array}{c}\text { Filter length } \\
(\mathrm{mm})\end{array}$ & $\begin{array}{c}\text { Tipping length } \\
(\mathrm{mm})\end{array}$ & $\begin{array}{c}\text { Menthol } \\
\text { flavor }\end{array}$ & $\begin{array}{c}\text { Subject } \\
\text { count }\end{array}$ & $\begin{array}{c}\text { Cigarette } \\
\text { count }\end{array}$ \\
\hline A & 1 & 100 & 25 & 30 & 36 & Yes & 50 & 641 \\
B & 1 & 100 & 25 & 30 & 36 & No & 49 & 662 \\
C & 1 & 85 & 25 & 27 & 32 & No & 49 & 658 \\
D & 3 & 100 & 25 & 31 & 35 & No & 48 & 619 \\
E & 5 & 100 & 25 & 31 & 35 & No & 49 & 680 \\
F & 5 & 100 & 25 & 30 & 36 & No & 44 & 687 \\
G & 6 & 100 & 23 & 31.5 & 36 & Yes & 48 & 682 \\
H & 6 & 100 & 23 & 31.5 & 37 & Yes & 49 & 582 \\
I & 9 & 100 & 17 & 27 & 32 & No & 36 & 266 \\
J & 9 & 100 & 25 & 30 & 36 & No & 49 & 657 \\
K & 9 & 85 & 25 & 27 & 31 & Yes & 49 & 552 \\
L & 10 & 85 & 25 & 27 & 32 & No & 50 & 716 \\
M & 11 & 85 & 25 & 27 & 32 & Yes & 49 & 717 \\
N & 11 & 100 & 25 & 31.5 & 36 & No & 48 & 538 \\
O & 14 & 100 & 25 & 30 & 36 & No & 47 & 600 \\
P & 16 & 85 & 25 & 21 & 26 & Yes & 47 & 651 \\
Q & 18 & 85 & 25 & 21 & 25 & Yes & 45 & 620 \\
\hline
\end{tabular}

a Nominal circumference.

Table 2. Mean \pm standard deviation and median butt lengths relative to tipping edge

\begin{tabular}{l|rr|r|r}
\hline & \multicolumn{2}{|c|}{ Cigarette } & \multicolumn{2}{c}{ Subject } \\
\cline { 2 - 5 } Code & Mean \pm SD & Median & Mean \pm SD & Median \\
\hline A & $8.3 \pm 7.3$ & 7.0 & $8.6 \pm 5.2$ & 8.0 \\
B & $6.3 \pm 5.7$ & 5.0 & $6.9 \pm 4.1$ & 5.8 \\
C & $8.5 \pm 8.0$ & 7.0 & $7.8 \pm 6.1$ & 7.7 \\
D & $8.8 \pm 7.0$ & 8.0 & $7.3 \pm 5.0$ & 7.0 \\
E & $8.4 \pm 7.2$ & 7.8 & $8.3 \pm 4.8$ & 9.8 \\
F & $8.9 \pm 7.9$ & 8.0 & $9.6 \pm 6.1$ & 9.8 \\
G & $9.4 \pm 8.5$ & 7.0 & $9.8 \pm 6.0$ & 9.0 \\
H & $5.3 \pm 6.3$ & 4.0 & $5.3 \pm 4.0$ & 5.0 \\
I & $6.4 \pm 6.2$ & 5.0 & $7.1 \pm 6.6$ & 6.1 \\
J & $6.1 \pm 6.1$ & 5.0 & $6.4 \pm 4.4$ & 6.4 \\
K & $8.4 \pm 7.3$ & 6.8 & $8.1 \pm 5.6$ & 6.5 \\
L & $6.1 \pm 6.0$ & 5.0 & $6.3 \pm 4.1$ & 6.0 \\
M & $8.2 \pm 7.3$ & 7.0 & $7.9 \pm 5.3$ & 7.0 \\
N & $8.1 \pm 7.7$ & 6.0 & $7.5 \pm 5.5$ & 5.3 \\
O & $7.8 \pm 7.2$ & 7.0 & $7.7 \pm 5.2$ & 7.3 \\
P & $13.9 \pm 8.1$ & 12.0 & $14.3 \pm 6.2$ & 12.0 \\
Q & $12.7 \pm 7.4$ & 12.0 & $12.1 \pm 5.4$ & 11.5 \\
All & $8.4 \pm 7.5$ & 6.7 & $8.3 \pm 5.7$ & 6.9 \\
\hline
\end{tabular}

to the cumulative percent curve. The point at which a column aligns with the curve is the percentage of cigarettes with that particular butt length or less. For example, the FTC/ISO (International Standard) specified butt length of $3 \mathrm{~mm}$ for machine smoking crosses the curve at approximately $30 \%$. This means that $30 \%$ of the cigarettes were smoked to this length or less and $70 \%$ of the cigarettes were smoked to a longer length. Only $24 \%$ of the cigarettes were smoked to a butt length less than $3 \mathrm{~mm}$.

The median length (50\% line) falls between the 6 and $7 \mathrm{~mm}$ bars. The calculated median was $6.7 \mathrm{~mm}$. The mean value was $8.4 \mathrm{~mm}$ with a standard deviation of $7.5 \mathrm{~mm}$. Counting all values of $-4 \mathrm{~mm}$ or less, $0.6 \%$ of the cigarettes were

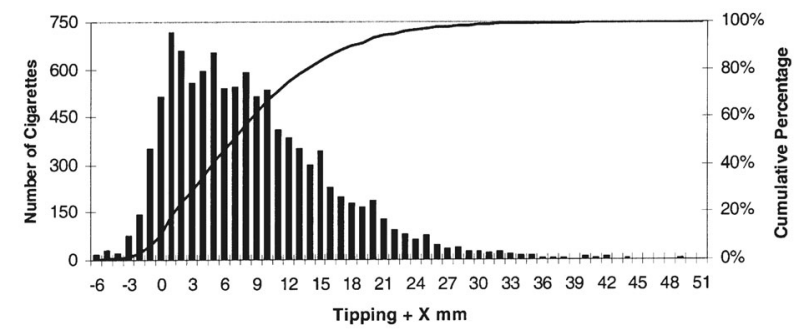

Figure 2. Histogram of individual cigarette butt lengths $(N=$ 10528) and cumulative distribution

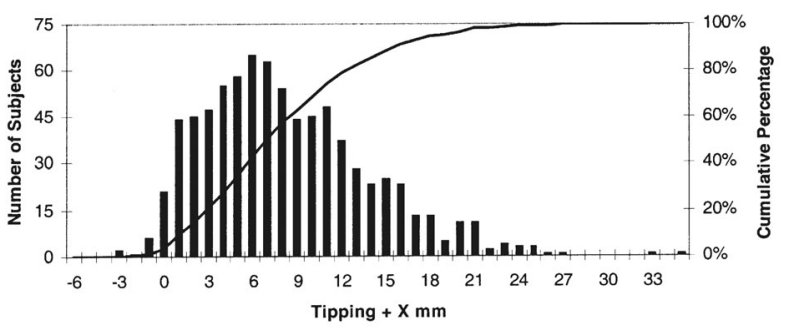

Figure 3. Histogram of mean butt length per subject $(N=803)$ and cumulative distribution

smoked to the filter. Only $6.0 \%$ of the cigarettes were smoked past the tipping overlap, and over half of these $(3.3 \%)$ were within $1 \mathrm{~mm}$ of the overlap. The calculated values for the $25^{\text {th }}$ and $75^{\text {th }}$ percentiles were 2.2 and $12.2 \mathrm{~mm}$, respectively.

Figure 3 is a histogram of the combined data for the individual subjects along with a cumulative per cent curve. The length smoked for each of the 803 subjects was averaged and combined to make this graph. Labeling is the same as for Figure 2. The median length was $6.9 \mathrm{~mm}$. The average length was $8.3 \mathrm{~mm}$ with a standard deviation of $5.7 \mathrm{~mm}$. The $25^{\text {th }}$ and $75^{\text {th }}$ percentiles were 3.6 and 11.1 $\mathrm{mm}$, respectively. None of the subjects consistently smoked 


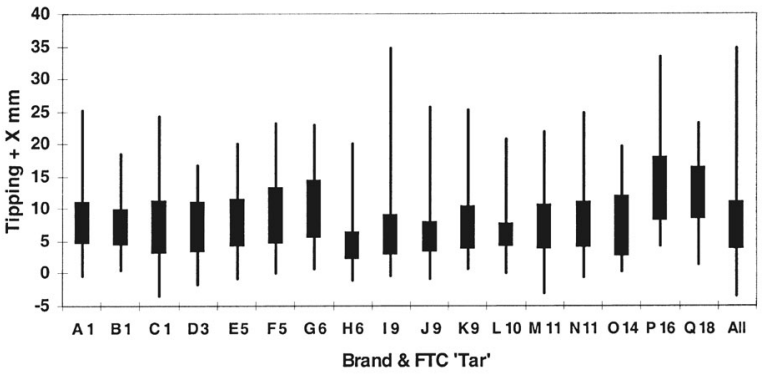

Figure 4. Minimum, $25^{\text {th }} \%, 75^{\text {th }} \%$, and maximum cigarette butt lengths by brand

to the filter. The sharp increase in the histogram between 0 and $1 \mathrm{~mm}$ indicates that the tipping edge is a powerful visual clue that the cigarette is finished. Nine of the subjects $(1.1 \%)$ smoked into the tipping; 2 subjects averaged $-3 \mathrm{~mm}, 1$ subject averaged $-2 \mathrm{~mm}$ and 6 subjects averaged $-1 \mathrm{~mm}$. Twenty-one of the subjects $(2.6 \%)$ smoked to the edge of the tipping overlap on average. Over $85 \%$ of the subjects smoked to an average butt length of tipping plus $3 \mathrm{~mm}$ or greater.

Figure 4 is a box-whisker plot for the individual brands using the averaged values for the subjects. The shaded box represents the $25^{\text {th }}$ to $75^{\text {th }}$ percentile for the brand. The lines (whiskers) represent the subject with the lowest and highest value for the brand. For example, for Brand A with $1 \mathrm{mg}$ FTC 'tar' (A 1), the subject with the shortest butt length smoked to the edge of the tipping $(0 \mathrm{~mm})$ on average and the subject with the longest butt length smoked to $25 \mathrm{~mm}$ on average. Twenty-five percent of the subjects smoked to a length of $5 \mathrm{~mm}$ or less and $75 \%$ of the subjects smoked to a length of $11 \mathrm{~mm}$ or less. The box-whisker diagram on the far right labeled 'All' is for all subjects for all brands combined.

\section{DISCUSSION}

From the data collected in this study, smoking into the tipping does not appear to be a method of compensatory smoking. For all of the cigarettes measured, only $6.0 \%$ were smoked past the tipping overlap and only $2.7 \%$ were smoked further than $1 \mathrm{~mm}$ past the tipping overlap. Since there had to be a small amount of time elapsed between taking the last puff and the cigarette extinguishing inside the collector, an additional $1 \mathrm{~mm}$ burnt after puffing is well within reason. Only 9 of the 803 subjects smoked past the tipping edge on average and 6 of these averaged smoking $1 \mathrm{~mm}$ past the tipping edge. In addition, using a single factor analysis of variance (ANOVA) there was no significant effect of FTC 'tar' yield on either mean $(p=0.72)$ or median $(p=0.92)$ butt length. The $R^{2}$ value for a linear regression of average butt length vs. FTC 'tar' was 0.24 ( $p$ $=0.04$ ) and was primarily driven by the two highest 'tar' products. Correlation with the median butt length gave an $R^{2}$ value of $0.12(p=0.16)$. The two highest 'tar' delivery products did have the longest butt lengths however. Other than these two, the other brands show no trend at all. The $R^{2}$ values fall to $0.03(p=0.57)$ and $0.08(p=0.31)$ for the average and median butt lengths correlated with FTC 'tar', respectively. If smoking into the tipping overlap were a method of compensatory smoking, then one would expect some sort of trend with FTC 'tar' yields, and none is evident.

The data presented here do not support any move to shorten butt lengths for standard machine smoking methods. Over $85 \%$ of the subjects and $70 \%$ of the cigarettes measured gave a butt length greater than or equal to tipping plus $3 \mathrm{~mm}$ as specified in the current FTC and ISO protocols. Median butt lengths were between tipping plus 6 to $7 \mathrm{~mm}$ and mean lengths were about tipping plus $8 \mathrm{~mm}$, whether calculated on a subject or a cigarette basis.

Measurements made in this study can be compared to some of the past studies. For the Canadian study by PORTER and DunN (14), the mean butt length including the filter was $33.2 \mathrm{~mm}$. Although tipping lengths were not stated, standard machine smoking butt lengths were quoted as being 24, 28, and $33 \mathrm{~mm}$ for $70 \mathrm{~mm}, 85 \mathrm{~mm}$, and $100 \mathrm{~mm}$ lengths, respectively. Using the sample percentages of $44.6 \%, 50.0 \%$, and $5.4 \%$ reported for each length, respectively, gives a weighted average machine smoked length of $26.5 \mathrm{~mm}$. Since this represents tipping plus $3 \mathrm{~mm}$, the average butt length was estimated as tipping plus $9.7 \mathrm{~mm}$. This is $1.3 \mathrm{~mm}$ greater that the mean cigarette value from this study. The small scale studies described in references (10-12) had averages ranging from tipping plus $5 \mathrm{~mm}$ to tipping plus $12 \mathrm{~mm}$ which bracket the results from this study equally. The 1972 studies by SCHULZ and the associated product filter lengths were found on the Brown \& Williamson document website (15). Filter lengths were $20 \mathrm{~mm}$ for all but one product which had a filter length of $21 \mathrm{~mm}$. With the $20 \mathrm{~mm}$ value, the calculated butt lengths would then be filter plus 13 to $14 \mathrm{~mm}$ for October and August 1972, respectively. Using a mid-range tipping overlap of $5 \mathrm{~mm}$ for this study gives an average length of about filter plus $13 \mathrm{~mm}$ which is essentially the same as in the 1972 studies. Thus, it appears that the average length smoked relative to either the filter or tipping has not changed in the last 25 to 30 years.

\section{REFERENCES}

1. U.S. Food and Drug Administration: Nicotine in cigarettes and smokeless tobacco products is a drug and these products are nicotine delivery devices under the federal food, drug, and cosmetic act; Federal Register, 21 CFR Part 801, 60 (1995) 41454-41787.

2. Grunberg, N.E., D.E. Morse, V.A. Maycock, and L.T. Kozlowski: Changes in overwrap and butt length of American filter cigarettes: An influence on reported tar yields; NY State Journal of Medicine, July 1985, 310-312.

3. Wilkenfeld, J., J. Henningfield, J. Slade, D. Burns, and J. Pinney: It's time for a change: Cigarette smokers deserve meaningful information about their cigarettes; J. Natl. Cancer Inst. 92 (2000) 90-91.

4. Henningfield, J.E., L.T. Kozlowski, and N.L. Benowitz: A proposal to develop meaningful labeling for cigarettes, JAMA 272 (1994) 312-314.

5. Schulz, W. and F. Seehofer: Über die Länge von Cigarettenstummeln in der Bundesrepublik Deutschland im Jahre 1968 [Examination of the cigarette butt 
length in 1968 in the Federal Republic of Germany]; Beitr. Tabakforsch. 5 (1970) 198-200.

6. Schulz, W.: Die Auswirkung der Tabaksteuererhöhung vom 1.9.1972 auf die Länge der Cigarettenstummel in der Bundesrepublik Deutschland [The influence of the tobacco tax increase of September 1st, 1972, in the Federal Republic of Germany on the butt lengths left by smokers]; Beitr. Tabakforsch. 7 (1974) 203-205.

7. Schulz, W. and F. Seehofer: Die Auswirkung der wirtschaftlichen Rezession auf die Länge der Cigarettenstummel in der Bundesrepublik Deutschland [The effect of the economic depression on the length of cigarette butts in the Federal Republic of Germany]; Beitr. Tabakforsch. 8 (1976) 455-458.

8. Schulz, W.: Die Auswirkung der Tabaksteuererhöhung vom 1.Juni 1982 auf die Länge der Cigarettenstummel in der Bundesrepublik Deutschland [The effect of the increase of tobacco tax on 1st of June 1982 on the length of cigarette butts in the Federal Republic of Germany]; Beitr. Tabakforsch. Int. 13 (1986) 215-218.

9. Schulz, W. and F. Seehofer: Smoking behavior in Germany - The analysis of cigarette butts (KIPA), in: Smoking behavior, edited by R.E. Thornton, Churchill Livingstone, London, 1978, 259-276.

10. Rawbone, R.G., K. Murphy, M.E. Tate, and S.J. Kane: The analysis of smoking parameter, inhalation and absorption of tobacco smoke in studies of human smoking behavior; in: Smoking behavior, edited by R. E. Thornton, Churchill Livingstone, London, 1978, 171-194.

11. Creighton, D.E. and P.H. Lewis: The effect of different cigarettes on human smoking patterns; in: Smoking behavior, edited by R. E. Thornton, Churchill Livingstone, London, 1978, 289-300.

12. Adams, P.I.: The influence of cigarette smoke yields on smoking habits; in: Smoking behavior, edited by R.E. Thornton, Churchill Livingstone, London, 1978, 349-360.
13. Djordjevic, M.V., D. Hoffmann, S. Thompson, and S.D. Stellman: Smoking behavior and exposure to select toxic agents among smokers of low and medium yield cigarettes; in: CORESTA Proceedings: Smoke and Technology Group, Brighton, England 11-15 October 1998, pp. 186-193.

14. Porter, A. and P. Dunn: Mouth insertion depths in Canadian smokers; Beitr. Tabakforsch. Int. 18 (1998) 85-91.

15. Schroder, R.: Progress Report April-Juni 1973, Bates No. 650036200-650036255 and Progress Report, JuliSeptember 1973, Bates No. 650036256-650036336, http://www.bwdocs.com/.

\section{ACKNOWLEDGEMENTS}

This work was funded by Brown \& Williamson Tobacco Corporation which subsequently merged with R.J. Reynolds Tobacco Company. Funding for the preparation of this manuscript was provided by British American Tobacco Limited, Group Research and Development, Southampton, UK. Special thanks are due to Mike Dixon and Derek Mariner for their helpful comments.

Corresponding author:

Kelley St.Charles

112 Raven Avenue,

Perry, GA, 31069

USA

E-mail: saintcl@alltel.net 